\title{
Probiotic Attributes, GABA-Producing Capacity and Cytotoxic Effects of Microbes Isolated from Thai Fermented Foods
}

\author{
Vijitra Luang-In ${ }^{1 *}$, Worachot Saengha ${ }^{1}$, Thippiya Karirat ${ }^{1}$, Sirirat Deeseenthum ${ }^{1}$, Benjaporn Buranrat ${ }^{2}$, Sutisa \\ Nudmamud-Thanoi ${ }^{3}$, Nyuk Ling $\mathrm{Ma}^{4}$ and Arjan Narbad ${ }^{5}$ \\ ${ }^{1}$ Natural Antioxidant Innovation Research Unit, Department of Biotechnology, Faculty of Technology, Mahasarakham \\ University, Khamriang, Kantarawichai, Maha Sarakham 44150, Thailand \\ ${ }^{2}$ Faculty of Medicine, Mahasarakham University, Muang, Maha Sarakham 44000, Thailand \\ ${ }^{3}$ Centre of Excellence in Medical Biotechnology, Department of Anatomy, Faculty of Medical Science, Naresuan University, \\ Phitsanulok 65000, Thailand \\ ${ }^{4}$ Faculty of Science and Marine Environment, Universiti Malaysia Terengganu, 21030, Kuala Nerus, Terengganu, Malaysia \\ ${ }^{5}$ Quadram Institute Bioscience, Norwich Research Park, Colney, Norwich NR4 7UA, UK \\ *For correspondence: vijitra.1@msu.ac.th; vijitra.luangin@gmail.com \\ Received 17 October 2020; Accepted 07 November 2020; Published 10 January 2021
}

\begin{abstract}
Mental illnesses and cancer deaths have been alarmingly increased in Thailand over the past decade. There is a search for an alternative remedy from natural sources. This work revealed the probiotic attributes of eighteen microbes from Thai fermented food sources, their neurotransmitter-producing capacities and cytotoxic effects. The probiotic attributes were comprehensively assessed by gelatin hydrolysis, antibiotic susceptibility, auto-aggregation, virulence gene detection, hemolytic activity, hydrophobicity determination, bile and acid tolerance. Neurotransmitters were produced from precursors by microbes over 3 days and analyzed by high-throughput LC-MS/MS. Cytotoxic effects of the selected microbial extracts on MCF-7, HepG2, and HeLa were determined using MTT assay. The results showed that only seven strains; Enterococcus casseliflavus 3.10A1, Enterobacter xiangfangensis 4A-2A3.1, Saccharomyces cerevisiae TC6, Pedicoccus pentosaceus WS11, Lactococcus lactis subspp. lactis TBRC 375, Lactobacillus brevis TBRC 3003 and Bifidobacterium adolescentis TBRC 7154 exhibited promising probiotic potential in every probiotic assessment. Only E. xiangfangensis 4A-2A3.1 and Bacillus spp. PS15 were capable of producing gamma-aminobutyric acid (GABA) from monosodium glutamate (20 mg/mL). GABA production of $4.60 \mu \mathrm{g} / \mathrm{mL}$ over 2 days was found in E. xiangfangensis 4A-2A3.1; however, Bacillus spp. PS15 produced the highest GABA at $5.57 \mu \mathrm{g} / \mathrm{mL}$ on day 1 . Moreover, B. adolescentis TBRC 7154 extract showed the lowest $\mathrm{IC}_{50}$ values against $\mathrm{MCF}-7$ (750.02 $\mu \mathrm{g} / \mathrm{mL})$, HepG2 $(681.08 \mu \mathrm{g} / \mathrm{mL})$, and HeLa $(425.50 \mu \mathrm{g} / \mathrm{mL})$ followed by E. xiangfangensis $4 \mathrm{~A}-2 \mathrm{~A} 3.1$, E. casseliflavus 3.10A1 and P. pentosaceus WS11. These microbes can be used as probiotic supplement with neurodegeneration preventive or chemopreventive potential. (C) 2021 Friends Science Publishers
\end{abstract}

Keywords: Anticancer; Neurotransmitter; Microbes; Probiotics; Thai fermented foods

\section{Introduction}

Although, modern drugs and chemotherapy are the routine remedies of mental disorders and cancers, they produce adverse effects in patients and have become ineffective after a certain time of usage (Weinstein et al. 2016). Thus, natural product-derived treatment has been sought after. Scientific evidence in the past decade have demonstrated that human gut microbiota play a vital role in human health, general well-being and brain function through the gut-brain axis (Claesson et al. 2012; Davari et al. 2013; Hsiao et al. 2013). The beneficial microbes in the human gut are defined as 'probiotics'. Probiotics can be assessed using the following tests: gelatin hydrolysis, antibiotic susceptibility, autoaggregation, PCR detection of virulence gene, hemolytic activity, bile and acid tolerance, hydrophobicity etc. for the necessary survival in human gastrointestinal tract.

The novel subclass of probiotics called 'psychobiotics' has been emerged since 2013. These psychobiotics were first defined as probiotics that, when ingested in appropriate quantities, yield positive psychiatric effects in psychopathology (Dinan et al. 2013). They were shown to be able to produce neurotransmitters and also exert psychotropic effects in animal model or patients. For example, Bifidobacterium and Lactobacillus were reported to produce gamma-aminobutyric acid (GABA) (Dinan et al. 2013). Bacillus, Escherichia and Saccharomyces produced norepinephrine. Streptococcus, Candida, Enterococcus and

To cite this paper: Luang-In V, W Saengha, T Karirat, S Deeseenthum, B Buranrat, S Nudmamud-Thanoi, NL Ma, A Narbad (2021). Probiotic attributes, GABA-producing capacity and cytotoxic effects of microbes isolated from Thai fermented foods. Intl J Agric Biol 25:409-419 
Escherichia produced serotonin. Serratia and Bacillus produced dopamine, and Lactobacillus produced acetylcholine (Dinan et al. 2013). Interestingly, endophytic Bacillus amyloquefaciens SB-9 isolated from grape wine produced melatonin, 5-hydroxytryptophan, serotonin and $\mathrm{N}$ acetylserotonin (Jiao et al. 2016).

In addition to neurotransmitter-producing capacity, certain microbes from fermented foods were shown to exhibit anticancer properties. The previous report showed that six lactic acid bacteria: Lactococcus lactis subspp. lactis, L. lactis subspp. cremoris, L. lactis subspp. lactis biovar diacetylactis, L. plantarum, L. meseuteroides subspp. cremoris and $L$. casei from the Japanese homemade kefir enhanced the cytotoxicity of human natural killer KHYG-1 cells to human chronic myelogenous leukemia K562 cells and colorectal tumor HCT116 cells (Yamane et al. 2018). In addition, $L$. plantarum isolated from kimchi was reported to strengthen phagocytosis, and exhibit cancer suppression in aseites carcinoma due to the polysaccharide chains of muramic acid in its cell well (Kim et al. 2011). Therefore, it is not surprised that probiotic bacteria have emerged as alternative treatment to human ailments and are extensively explored as biotherapeutics.

The bacterial genera mentioned above have been isolated from Thai fermented foods (water kefir, milk kefir, and fermented foods in Thailand) in the previous works (Luang-In and Deseenthum 2016; Luang-In et al. 2018a, b). Fermentation seems to be the lowest cost process to obtain probiotics-enriched functional foods. However, little is known about their probiotic attributes, neurotransmitterproducing potentials and cytotoxic effects on cancer cells.

Thus, the aims of this work were to determine which bacteria isolated from Thai fermented foods possessed probiotic attributes, neurotransmitter-producing capacity and cytotoxic effects on MCF-7, HepG2, and HeLa cells. The results provided the possibility to develop the novel probiotic/psychobiotic-rich functional foods or pills or cocktails at low cost to exert neurodegeneration preventive or chemopreventive effects.

\section{Materials and Methods}

\section{Microbial sources}

Eighteen microbial species were isolated from various Thai fermented foods (Luang-In and Deseenthum 2016), Thai milk kefir from Kamphaeng Phet Province, Thailand (Luang-In et al. 2018a) and Thai water kefir from Nakhon Ratchasima Province, Thailand (Luang-In et al. 2018b). All microbes were stored in $20 \%$ glycerol stocks at $-80^{\circ} \mathrm{C}$ at Natural Antioxidant Innovation Research Unit, Department of Biotechnology, Mahasarakham University, Thailand. Three bacterial strains including Lactococcus lactis subspp. lactis TBRC 375, Lactobacillus brevis TBRC 3003 isolated from pickled cabbage (Brassica spp.) and Bifidobacterium adolescentis TBRC 7154 isolated from human intestine were purchased from Thailand Bioresource Research Center (TBRC), Pathum Thani, Thailand and used as probiotic references.

\section{Culture of microbial strains}

Isolated acetic acid bacteria (AAB) strains, Enterobacter spp. and Enterococcus spp. were cultivated in Luria-Bertani broth (LB) pH $6.8(10 \mathrm{~g} / \mathrm{L}$ tryptone, $10 \mathrm{~g} / \mathrm{L} \mathrm{NaCl}, 5 \mathrm{~g} / \mathrm{L}$ yeast extract). Lactic acid bacteria (LAB) strains were cultured in de Man, Rogosa and Sharpe (MRS) broth pH 6.8 (Difco, Detroit, MI, USA). Bacillus spp. was cultured in Tryptic Soy Broth (TSB) pH 6.8 (17 g/L tryptone, $3 \mathrm{~g} / \mathrm{L}$ phytone, $5 \mathrm{~g} / \mathrm{L} \mathrm{NaCl}, 2.5 \mathrm{~g} / \mathrm{L}$ glucose). Yeasts were grown in Yeast Peptone Dextrose (YPD) agar pH $7.0(20 \mathrm{~g} / \mathrm{L}$ glucose, $10 \mathrm{~g} / \mathrm{L}$ yeast and $20 \mathrm{~g} / \mathrm{L}$ peptone). All microbial cultures were anaerobically cultured for $24 \mathrm{~h}$ at $37^{\circ} \mathrm{C}$, except yeasts and $\mathrm{AAB}$ that were aerobically cultured $30^{\circ} \mathrm{C}$ and $37^{\circ} \mathrm{C}$, respectively. Standard cultures were prepared by inoculation of $10 \mathrm{~mL}$ corresponding broth with $10 \mu \mathrm{L}$ of bacterial culture in a frozen stock $\left(-80^{\circ} \mathrm{C}\right)$ and incubated at $37^{\circ} \mathrm{C}$ for $24 \mathrm{~h}$. The cultures were then subsequently sub-cultured in $10 \mathrm{~mL}$ corresponding broth for $24 \mathrm{~h}$ at $37^{\circ} \mathrm{C}$ prior to inoculation into the test tubes for further assessments.

\section{Assessments of probiotic properties of microbes}

Gelatin hydrolysis: Gelatin hydrolysis due to the presence of gelatinase was assessed by spotting $1 \mu \mathrm{L}$ of the $24 \mathrm{~h}$ microbial cultures onto the surface of Luria Bertani agar slants (BD, Franklin Lakes, NJ, USA) containing 3\% (w/v) gelatin (BD, Franklin Lakes, NJ, USA) and incubated for 48 $\mathrm{h}$ at $37^{\circ} \mathrm{C}$. Afterwards, the slants were maintained at $4{ }^{\circ} \mathrm{C}$ for $4 \mathrm{~h}$. Gelatin hydrolysis was recorded as positive when gelatin became liquid, and negative when gelatin was still solid (Zommiti et al. 2018).

\section{Antibiotic susceptibility}

Antibiotic susceptibility tests were conducted as per the National Committee for Clinical Laboratory Standards using the disk diffusion method (Wayne 2002). Six antibiotics, tetracycline, chloramphenicol, erythromycin, vancomycin, penicillin and streptomycin, were used in this study. All strains were sub-cultured two times from the frozen stock into $10 \mathrm{~mL}$ of corresponding broth and were incubated at $37^{\circ} \mathrm{C}$ for $24 \mathrm{~h}$. These cultures were then spread on plates containing $20 \mathrm{~mL}$ of corresponding agar and then antibiotic disks (HiMedia, India) were placed on the surface of agar plates and then were incubated at $37^{\circ} \mathrm{C}$ for $24 \mathrm{~h}$. Inhibition zones in diameters were recorded in triplicate and compared to score strains as resistant (R: $\leq 15 \mathrm{~mm})$, moderate susceptibility (M: 16-20 mm) and susceptible (S: $\geq 21 \mathrm{~mm}$ ) (Lapsiri et al. 2011), while streptomycin was reported as Minimal Inhibitory Concentration (MIC). 


\section{Autoaggregation}

Auto-aggregation of the microbial strains was tested as in the previous study (Collado et al. 2008). Overnight cultures were centrifuged at 8,000 g for $10 \mathrm{~min}$. The cell pellets were washed twice with Phosphate Buffer Saline (PBS) pH 7.4, and resuspended into PBS $\left(10^{8} \mathrm{CFU} / \mathrm{mL}\right)$. Cell suspensions $(4 \mathrm{~mL})$ were vortex-mixed for $20 \mathrm{~s}$ and the absorbance was measured at $600 \mathrm{~nm}\left(\mathrm{~A}_{600}\right)$ after incubation at $0 \mathrm{~h}$ and $24 \mathrm{~h}$.

$$
\text { Autoaggregation }(\%)=\left[1-\left(A_{24} \mathrm{~h} / A_{0}\right) \times 100\right]
$$

Where $A_{24}$ refers to the absorbance of the suspension at 24 $\mathrm{h}$ and $A_{0}$ refers to the absorbance at time 0 .

\section{Hemolytic activity}

Microbial cultures were streaked on blood agar plates supplemented with $5 \%$ (w/v) of sheep blood (EnvioMed, Thailand) in triplicate and incubated at $37^{\circ} \mathrm{C}$ for $48 \mathrm{~h}$. Afterwards, the hemolytic activity was as scored as partial hydrolysis of the red blood cells by the appearance of a green zone ( $\alpha$-hemolysis), the total hydrolysis of red blood cells by clear zone appearance ( $\beta$-hemolysis) or no reaction ( $\gamma$-hemolysis).

\section{Detection of virulence genes by PCR}

Six virulence genes from all Enterococcus strains were determined by PCR screening. These genes included: (1) agg (Aggregation substance) for adhesion, Fwd primer: 5'AAGAAAAAGAA GTAGACCAAC 3', Rev primer: 5'AAACGGCAAGAC AAGTAAATA3', 1553 bp, annealing temp. $55^{\circ} \mathrm{C}$. (2) VanA (Vancomycin resistance), Fwd primer: 5' CGGGGAAGATGGCAGTAT 3', Rev primer: 5' CGCAGGGACGGTGATTTT 3', 732 bp, annealing temp. $55^{\circ} \mathrm{C}$. (3) gelE (Gelatinase) for translocation, Fwd primer: 5' ACCCCGTATCATTGGTTT 3', Rev primer: 5' ACGCATTGCTTTT CCATC 3', 419 bp, annealing temp. $54^{\circ} \mathrm{C}$. (4) Ent (Enterocins) for antilisteria, Fwd primer: 5' AAATATTATGGAAATGGAGTGTAT 3', Rev primer: 5' CTCGTTAAGGTCCCTTCACG 3', 475 bp, annealing temp. $53^{\circ} \mathrm{C}$. (5) CylA (Cytolysin) for cell lysis, Fwd primer: 5' ACTCGGGGATTGATAGGC 3', Rev primer: 5' GCTGCTAAAGCTGCGCTT 3', 688 bp, annealing temp. $55^{\circ} \mathrm{C}$. (6) $\mathrm{Hyl}$ (Hyaluronidase) for translocation, Fwd primer: GAGTAGAGGAATATCTTAGC 3', Rev primer: 5' AGGCTCCAATTCTGT 3', 661 bp, annealing temp. $54^{\circ} \mathrm{C}$. The PCR reaction cocktail $(25 \mu \mathrm{L})$ was as follows: gDNA template $(0.02-5 \mu \mathrm{g}, 2 \mu \mathrm{L})$, forward primer $(0.1-$ $1 \mu \mathrm{M}, 1 \mu \mathrm{L})$, reverse primer $(0.1-1 \mu \mathrm{M}, 1 \mu \mathrm{L})$, One PCR mixture buffer (GeneDirex, Bio-Helix Co. Ltd., Taiwan) $(1 \times, 12.5 \mu \mathrm{L})$ and nuclease-free water $(8.5 \mu \mathrm{L})$. The PCR conditions in PCR thermocycler (Hybaid P $\times 2$
Thermo Scientific, USA) were as follows: (1) initial denaturation at $94^{\circ} \mathrm{C}$ for $1 \mathrm{~min}$, (2) 32 cycles of denaturation at $94^{\circ} \mathrm{C}$ for $1 \mathrm{~min}$, annealing at $53-55^{\circ} \mathrm{C}$ for $1 \mathrm{~min}$ and extension at $72^{\circ} \mathrm{C}$ for $1 \mathrm{~min}$ (3) final extension at $72^{\circ} \mathrm{C}$ for $10 \mathrm{~min}$. DNA bands were analyzed on $0.8 \%$ agarose gel electrophoresis using Gel Documentation (Thermo Scientific, USA).

\section{Cell surface hydrophobicity}

Cell surface hydrophobicity relates to the microbial adherence to hydrocarbons. The higher cell surface hydrophobicity suggests the better probiotic attribute (Grajek et al. 2016). Overnight cultures were centrifuged at 4,000 $\mathrm{g}$ for $10 \mathrm{~min}$. After centrifugation, the cell pellet was resuspended in PBS ( $\mathrm{pH}$ 7.4). This procedure was repeated one more time. The cell suspension was then diluted with the PBS buffer to an absorbance at value of 0.5 in $3 \mathrm{~mL}$, when measured at $600 \mathrm{~nm}$. N-hexadecane $(1 \mathrm{~mL})$ was added to cell suspension culture, vortex-mixed for $2 \mathrm{~min}$ and incubated at $37^{\circ} \mathrm{C}$ until phase separation was observed. Subsequently, the absorbance of bacterial cells in the collected aqueous phases was determined at the $600 \mathrm{~nm}$ wavelength. The percentage of cell surface hydrophobicity was calculated from the formula:

$$
\mathrm{H} \%=\left(\mathrm{A}_{0}-\mathrm{A}\right) \times 100 \% / \mathrm{A}_{0}
$$

Where $\mathrm{A} 0$ - is the absorbance of microbial cultures prior to the addition of $\mathrm{n}$ hexadecane and $\mathrm{A}$ is the absorbance after the addition of $n$-hexadecane measured at the aqueous phase

\section{Tolerance to gastric acid}

This was carried out according to Guo et al. (2015). Overnight cultures were harvested $\left(12,000 \mathrm{~g}, 10 \mathrm{~min}, 4^{\circ} \mathrm{C}\right)$. The cell pellets were washed twice with sterile saline buffer $(0.85 \%)$, and subsequently were resuspended in corresponding broth adjusted by $\mathrm{HCl}$ to $\mathrm{pH}$ 3.0. The cultures were anaerobically incubated at $37^{\circ} \mathrm{C}$ for $1.30 \mathrm{~h}$. Viable cell counting was conducted using the plate count method. Each sample $(1 \mathrm{~mL})$ was collected at $0 \mathrm{~h}$ and $1.30 \mathrm{~h}$ under sterile conditions, and made in 10-fold serial dilutions with sterile saline buffer $(0.85 \%)$. The dilutions were plated on corresponding agars and anaerobically incubated at $37^{\circ} \mathrm{C}$ for $24 \mathrm{~h}$ before calculation in $\log _{10} \mathrm{CFU} / \mathrm{mL}$ and survival rate $(\%)$ was calculated from (cell number at final time/cell number at initial time) $\times 100 \%$.

\section{Tolerance to bile salts}

Tolerance to bile salts was conducted as in the previous method (Guo et al. 2015). Overnight cultures were harvested $(12,000 \mathrm{~g}, 10 \mathrm{~min})$. Cell pellets were washed twice with sterile saline buffer $(0.85 \% \mathrm{NaCl})$, and subsequently resuspended in corresponding broths 
supplemented with $0.3 \%$ (w/v) oxgall (Amresco, USA) at $37^{\circ} \mathrm{C}$ under anaerobic conditions. Each sample $(1 \mathrm{~mL})$ was collected at $0 \mathrm{~h}$ and $3 \mathrm{~h}$ and made in 10-fold serial dilutions with sterile saline buffer $(0.85 \%)$. The dilutions were plated on corresponding agars and anaerobically incubated at $37^{\circ} \mathrm{C}$ for $24 \mathrm{~h}$ before calculation in $\log _{10} \mathrm{CFU} / \mathrm{mL}$ and the survival rate $(\%)$ was calculated from (cell number at final time/cell number at initial time) $\times 100 \%$.

\section{Screening for neurotransmitter-producing microbes by LC-MS/MS}

Microbial cultures were cultured in $1 \mathrm{~mL}$ LB broths containing $20 \mathrm{mg} / \mathrm{mL}$ monosodium glutamate (MSG) (HiMedia, India), $200 \mathrm{mg} / \mathrm{L}$ L-tryptophan (HiMedia, India), $200 \mathrm{mg} / \mathrm{L}$ L-tyrosine (HiMedia, India) and 0.15 $\mathrm{m} M$ pyridoxal-5 phosphate as co-factor for GABAsynthesizing enzyme (TCI, Japan) at $37^{\circ} \mathrm{C}$ for $24,48,72$ h. Culture broths were centrifuged at $16,000 \mathrm{~g}$ for $5 \mathrm{~min}$ and supernatant was filtered through a $0.22-\mu \mathrm{m}$ filter and the filtrates were used directly for LC-MS/MS analysis. The operating conditions used for LC-MS/MS and specific parameters were as follows: Shidmazu SIL20AC model with Insertsil ODS-3 C18 column (150 mm $\times 2.1 \mathrm{~mm}$ ) was used, the flow rate was $0.2 \mathrm{~mL} / \mathrm{min}$, the injection volume was $2 \mu \mathrm{L}$, mobile phase $\mathrm{A}$ was acetonitrile and mobile phase B was $0.45 \%$ formic acid, the run time was $10 \mathrm{~min}$, oven model was CTO-20AC at $38^{\circ} \mathrm{C}$, acquisition mode was MRM, CID gas was $230 \mathrm{kV}$ and interface volt was $4.59 \mathrm{kV}$. GABA $(\mathrm{Mw}=103.12)$ was eluted at the retention time $1.65 \mathrm{~min}$, the parent ion was $104(\mathrm{~m} / \mathrm{z})$ and the daughter ion was $87(\mathrm{~m} / \mathrm{z})$.

\section{Cancer cell lines}

The human cervical adenocarcinoma (HeLa), breast adenocarcinoma (MCF-7), and hepatocellular carcinoma (HepG2) cancer cell lines were obtained from the American Type Culture Collection (ATCC; Manassas, VA, USA) in Dulbecco's Modified Eagle's Medium (DMEM), supplemented with $10 \%$ of fetal bovine serum and 100 $\mathrm{U} / \mathrm{mL}$ of penicillin, $100 \mu \mathrm{g} / \mathrm{mL}$ of streptomycin, then incubated at $37^{\circ} \mathrm{C}$ under $5 \% \mathrm{CO}_{2}$. DMEM media for cell lines cultures were renewed every 2-3 days until $80 \%$ confluency was reached. Cultured cell lines were washed with PBS, pH 7.2 before trypsinization with $0.25 \%$ TrypsinEDTA. DMEM media were added to cell lines and the cell colonies were counted using inverted microscope (NIB9000, Xenon, China).

\section{Crude microbial extraction for cytotoxicity assay}

Overnight cultures $(1 \% \mathrm{v} / \mathrm{v})$ were inoculated in corresponding broths $(100 \mathrm{~mL})$ in $500 \mathrm{~mL}$ flasks at $37^{\circ} \mathrm{C}$ at $200 \mathrm{rpm}$ for 2 days. Negative controls were broths without microbial inoculations. The crude microbial extracts were obtained from whole cultures; consisting of microbial cells and broths. After that, $100 \mathrm{~mL}$ ethyl acetate (ETAC) was added to microbial cultures for crude microbial extraction at $37^{\circ} \mathrm{C}$ at $200 \mathrm{rpm}$ for $6 \mathrm{~h}$ and the ETAC layer was separated and dried using a rotatory evaporator, dissolved in $95 \%$ ethanol and stored at $-20^{\circ} \mathrm{C}$ till further analysis.

\section{Cytotoxicity assay}

Cytotoxicity was measured using 3-(4,5-dimethylthiazolyl2)-2, 5-diphenyltetra zolium bromide (MTT) assay (Sigma, USA) following the previous method (Siddiqui et al. 2017). MCF-7, HeLa and HepG2 cells $\left(5 \times 10^{3}\right.$ cells $\left./ \mathrm{mL}\right)$ were pipetted into 96 -well plates and incubated at $37^{\circ} \mathrm{C}$ under $5 \%$ $\mathrm{CO}_{2}$ for $72 \mathrm{~h}$. Crude microbial extracts $(0,400,600,800$ and $1,000 \mu \mathrm{g} / \mathrm{mL}$ ) were added to wells and incubated for $72 \mathrm{~h}$. MTT $(5 \mathrm{mg} / \mathrm{mL})$ dissolved in PBS buffer ( $\mathrm{pH}$ 7.2) was added to the wells and incubated at $37^{\circ} \mathrm{C}$ under $5 \% \mathrm{CO}_{2}$ for $4 \mathrm{~h}$. MTT was removed and $200 \mu \mathrm{L}$ DMSO was added to dissolve the formazan and the purple color appeared if cells were alive. Doxorubicin was used as a positive control. The absorbance was measured at $590 \mathrm{~nm}$ using microplate reader (M965+, Mastertech, Taiwan). Cytotoxicity of crude microbial extracts against cancer cells was measured as $\mathrm{IC}_{50}$ value. When $\%$ cytotoxicity was $\leq 50 \%$, it represented noncytotoxic effect and when $\%$ cytotoxicity was $>50 \%$, it represented cytotoxic effect. Cell morphology was also observed using an inverted microscope (NIB-100, Xenon, China).

\section{Statistical analysis of data}

Data were collected in triplicate and results were reported as means \pm standard deviation (SD). Statistical analysis was performed using one-way analysis of variance (ANOVA) and Duncan multiple range test by the software S.P.S.S. (demo version) was used to separate the means at $p<0.05$.

\section{Results}

\section{Probiotics attributes of microbes}

The result showed that half of all microbes exhibited gelatin hydrolysis or gelatinase activity. Those included all Bacillus spp., L. casei WS13, WS15, A. pasteurianus WS3 and WS4. However, Enterococcus spp., Enterobacter spp., M. guilliermondii TC15, S. cerevisiae TC6, P. pentosaceus and certain $A$. pasteurianus showed negative results i.e., no gelatinase (Table 1). The percentage of auto-aggregation at 5 $\mathrm{h}$ was ranged from 13.57 to $84.53 \%$ and at $24 \mathrm{~h}$ from 23.92 to $97.38 \%$. In all strains, as time passed by from $5 \mathrm{~h}$ to $24 \mathrm{~h}$, the percentage of auto-aggregation increased. Only two strains; E. xiangfangensis 4A-2A3.1 and Enterobacter spp. $1 \mathrm{~B}-2$ had less than $50 \%$ percentage of auto-aggregation at 
Table 1: Gelatin hydrolysis, auto-aggregation and hemolysis properties of microbes

\begin{tabular}{|c|c|c|c|c|c|c|}
\hline No. & Microbial strains & Source & Gelatin hydrolysis & Auto-aggregation (\%) at $5 \mathrm{~h}$ & Auto-aggregation (\%) at $24 \mathrm{~h}$ & Hemolysis level \\
\hline 1 & Enterococcus casseliflavus $\mathrm{SB} 2 \times 2$ & $\mathrm{PC}$ & - & $80.41 \pm 0.53^{\mathrm{c}}$ & $95.29 \pm 0.00^{\mathrm{b}}$ & $\beta$ \\
\hline 2 & Enterobacter ludwigii S1E9 & PC & - & $69.09 \pm 0.14^{\mathrm{h}}$ & $72.86 \pm 0.16^{\mathrm{i}}$ & $\gamma$ \\
\hline 3 & E. xiangfangensis 4A-2A3.1 & $\mathrm{PC}$ & - & $27.77 \pm 0.11^{\mathrm{m}}$ & $42.14 \pm 0.11^{\mathrm{m}}$ & $\gamma$ \\
\hline 4 & E. casseliflavus 3.10A1 & $\mathrm{PC}$ & - & $45.33 \pm 0.00^{\mathrm{k}}$ & $67.125 \pm 0.49^{j}$ & $\gamma$ \\
\hline 5 & Enterobacter spp.1B-2 & $\mathrm{PC}$ & - & $6.13 \pm 0.25^{\circ}$ & $23.92 \pm 0.25^{\mathrm{n}}$ & $\gamma$ \\
\hline 6 & Bacillus siamensis PS23 & MK & + & $78.42 \pm 0.08^{\mathrm{d}}$ & $61.42 \pm 0.65^{\mathrm{k}}$ & $\alpha$ \\
\hline 7 & B. subtilis KW5 & MK & + & $70.44 \pm 0.90^{\mathrm{g}}$ & $97.38 \pm 0.00^{\mathrm{a}}$ & $\alpha$ \\
\hline 8 & B. tequilensis PS21 & MK & + & $74.37 \pm 0.00^{\mathrm{e}}$ & $84.10 \pm 0.13^{g}$ & $\beta$ \\
\hline 9 & Bacillus spp. PS15 & MK & + & $82.54 \pm 0.26^{\mathrm{b}}$ & $86.43 \pm 0.40^{\mathrm{f}}$ & $\gamma$ \\
\hline 10 & Lactobacillus casei WS13 & WK & + & $71.79 \pm 0.13^{\mathrm{f}}$ & $92.82 \pm 1.89^{\mathrm{c}}$ & $\alpha$ \\
\hline 11 & Meyerozyma guilliermondii TC15 & WK & - & $13.57 \pm 1.52^{\mathrm{n}}$ & $54.00 \pm 0.13^{1}$ & $\gamma$ \\
\hline 12 & Acetobacter pasteurianus WS4 & WK & + & $57.68 \pm 0.57^{\mathrm{j}}$ & $81.43 \pm 1.07^{\mathrm{h}}$ & $\alpha$ \\
\hline 13 & L. casei WS15 & WK & + & $57.21 \pm 1.03^{\mathrm{j}}$ & $92.06 \pm 0.10^{\mathrm{cd}}$ & $\beta$ \\
\hline 14 & Saccharomyces cerevisiae TC6 & WK & - & $64.88 \pm 0.38^{\mathrm{i}}$ & $81.30 \pm 0.23^{h}$ & $\gamma$ \\
\hline 15 & Pedicoccus pentosaceus WS12 & WK & - & $81.50 \pm 0.14^{\mathrm{bc}}$ & $91.11 \pm 0.25^{\mathrm{de}}$ & $\gamma$ \\
\hline 16 & Pedicoccus pentosaceus WS11 & WK & - & $84.53 \pm 0.10^{\mathrm{a}}$ & $90.36 \pm 0.21^{\mathrm{e}}$ & $\gamma$ \\
\hline 17 & A. pasteurianus WS3 & & + & $77.59 \pm 1.31^{\mathrm{d}}$ & $91.99 \pm 0.14^{\mathrm{cd}}$ & $\alpha$ \\
\hline 18 & A. pasteurianus WS7 & WK & - & $33.63 \pm 0.18^{1}$ & $85.93 \pm 0.11^{\mathrm{f}}$ & $\alpha$ \\
\hline 19 & Lactococcus lactis subspp. lactis TBRC 375 & PC & - & $77.77 \pm 0.21^{\mathrm{m}}$ & $92.14 \pm 0.17^{\mathrm{m}}$ & $\gamma$ \\
\hline 20 & L. brevis TBRC 3003 & $\mathrm{PC}$ & - & $56.00 \pm 0.11^{\mathrm{m}}$ & $75.00 \pm 1.41^{\mathrm{m}}$ & $\gamma$ \\
\hline 21 & Bifidobacterium adolescentis TBRC 7154 & intestine & - & $69.00 \pm 1.41^{\mathrm{m}}$ & $82.00 \pm 0.11^{\mathrm{m}}$ & $\gamma$ \\
\hline
\end{tabular}

Means with same lower-case letter did not differ significantly from each other according to Duncan Multiple range's test at $P<0.05$

PC $=$ Pickled cabbage; MK = Milk kefir; WK = Water kefir

both $5 \mathrm{~h}$ and $24 \mathrm{~h}$. Four microbial strains including $E$. casseliflavus 3.10A1, P. pentosaceus WS12, E. casseliflavus $\mathrm{SB} 2 \times 2$ and $P$. pentosaceus WS11 exhibited > $80 \%$ auto-aggregation at both 5 and $24 \mathrm{~h}$ (Table 1) suggesting they are most likely to attach to colonocytes in the human gut. The highest percentage of autoaggregation at $24 \mathrm{~h}$ was found in B. subtilis KW5 (97.38\%) and at $5 \mathrm{~h}$ was found in $P$. pentosaceus WS11 (84.53\%). The results showed that only 3 microbial strains including $E$. casseliflavus SB2x2, B. tequilensis PS21 and L. casei WS15 exhibited $\beta$-hemolysis which may present harm to human health since it may cause hemolysis. The remaining strains showed $\gamma$-hemolysis and $\alpha$-hemolysis indicating safety for use as probiotic in humans (Table 1).

The results showed that only four bacterial strains (Table 2) namely E. casseliflavus $3.10 \mathrm{~A} 1$, B. siamensis PS23, A. pasteurianus WS4, and A. pasteurianus WS3 were susceptible to all six antibiotics; tetracycline, chloramphenicol, erythromycin, vancomycin, penicillin and streptomycin. In addition, most of the tested microbial strains appeared to be moderate susceptible or susceptible to most of the six antibiotics used in this work. However, $E$. ludwigii S1E9, Enterobacter spp. 1B-2 and Bacillus spp. PS15 were found resistant to three or four antibiotics.

Virulence in enterococci is linked to several factors, such as ace, agg, ccf, cpd, cob, cylL, esp, gel $\mathrm{E}$, and $e f a \mathrm{~A}$ and formation of biofilm (Chuang-Smith et al. 2010). Here, the presence of 6 virulence genes including (1) agg (Aggregation substance) for adhesion, (2) VanA (Vancomycin resistance), (3) gelE (Gelatinase) for translocation, (4) Ent (Enterocins) for antilisteria, (5) CylA (Cytolysin) for cell lysis, and (6) $\mathrm{Hyl}$ (Hyaluronidase) for translocation was evaluated. This is the first report of investigating the occurrence of agg, VanA, gelE, Ent, CylA

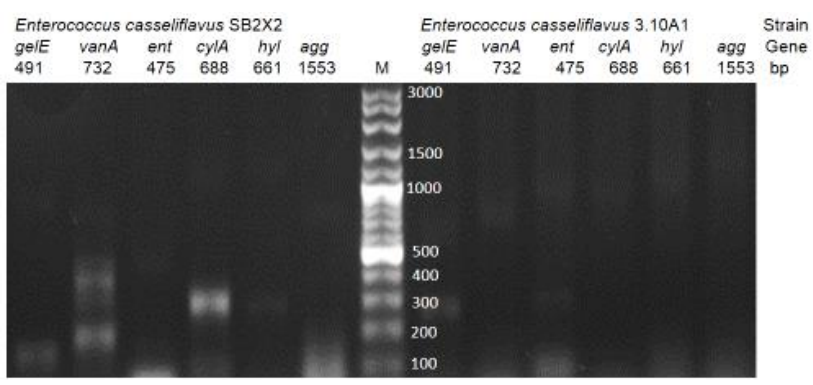

Fig. 1: PCR products of virulence genes in E. casseliflavus SB2x2 and $E$. casseliflavus 3.10A1on agarose gel electrophoresis

and $H y l$ genes in E. casseliflavus isolated from Thai fermented foods. The results showed no virulence gene products with designated sizes in E. casseliflavus SB2x 2 or E. casseliflavus 3.10A1 (Fig. 1). However, the product band of $300 \mathrm{bp}$ for CylA from E. casseliflavus SB2x2 may confirm $\beta$-hemolysis result of $E$. casseliflavus SB2x2 suggesting that it may express CylA (Cytolysin) for red blood cell autolysis. The PCR products of 400 and $150 \mathrm{bp}$ of $\operatorname{VanA}$ in E. casseliflavus SB2x2 may be results of non-specific annealing of primers that did not correspond to vancomycin susceptibility of this strain. Thus, E. casseliflavus 3.10A1 with better safety (i.e., $\gamma$-hemolysis and no virulence genes) was chosen over E. casseliflavus SB2x2.

Twelve out of twenty-one microbes from the previous assessments were selected for the next experiment based on promising results from each evaluation. The results showed that eight out of twelve microbial strains including $E$. casseliflavus 3.10A1, E. xiangfangensiss 4A-2A3.1, S. cerevisiae TC6, M. guilliermondii TC15, P. pentosaceus WS11, L. lactis subspp. lactis TBRC 375, L. brevis TBRC 3003 and B. adolescentis TBRC 7154 were classified as low 
Table 2: Antibiotics susceptibility of microbes

\begin{tabular}{|c|c|c|c|c|c|c|}
\hline \multirow{2}{*}{ Microbial strains } & \multicolumn{5}{|c|}{ Clear zone $(\mathrm{mm})$} & \multirow{2}{*}{$\begin{array}{l}\text { MIC } \\
\text { Streptomycin }(\mu \mathrm{g}) \\
\end{array}$} \\
\hline & Tetracycline $(30 \mu \mathrm{g})$ & Penicillin (10 IU) & Chloramphenicol $(30 \mu \mathrm{g})$ & Erythromycin $(15 \mu \mathrm{g})$ & Vancomycin $(30 \mu \mathrm{g})$ & \\
\hline Enterococcus & 28 & 22 & 29 & 25 & 22.5 & 1 \\
\hline casseliflavus $\mathrm{SB} 2 \times 2$ & $\mathrm{~S}$ & $\mathrm{~S}$ & $\mathrm{~S}$ & $\mathrm{~S}$ & $\mathrm{~S}$ & $\mathrm{~S}$ \\
\hline \multirow[t]{2}{*}{ E. ludwigii S1E9 } & 17 & 0 & 22 & 0 & 0 & 0 \\
\hline & M & $\mathrm{R}$ & $\mathrm{S}$ & $\mathrm{R}$ & $\mathrm{R}$ & $\mathrm{R}$ \\
\hline E. xiangfangensis 4A- & 10 & 22 & 24.5 & 19.5 & 18 & 5 \\
\hline $2 \mathrm{~A} 3.1$ & $\mathrm{R}$ & $\mathrm{S}$ & $\mathrm{S}$ & M & M & $\mathrm{S}$ \\
\hline \multirow{2}{*}{ E. casseliflavus 3.10A1 } & 28 & 16 & 25 & 18.5 & 18.5 & 3 \\
\hline & $\mathrm{S}$ & M & $\mathrm{S}$ & M & M & $\mathrm{S}$ \\
\hline \multirow{2}{*}{ Enterobacter spp.1B-2 } & 17 & 0 & 22 & 0 & 0 & 5 \\
\hline & $\mathrm{M}$ & $\mathrm{R}$ & $\mathrm{S}$ & $\mathrm{R}$ & $\mathrm{R}$ & $\mathrm{S}$ \\
\hline \multirow[t]{2}{*}{ Bacillus siamensis PS23 } & 19.5 & 21 & 24.5 & 25.5 & 16.5 & 3 \\
\hline & M & $\mathrm{S}$ & $\mathrm{S}$ & $\mathrm{S}$ & M & $\mathrm{S}$ \\
\hline \multirow[t]{2}{*}{ B. subtilis Y31.1 KW5 } & 20 & 20 & 28.5 & 22 & 18 & 0 \\
\hline & $\mathrm{S}$ & $\mathrm{S}$ & $\mathrm{S}$ & $\mathrm{S}$ & M & $\mathrm{R}$ \\
\hline \multirow{2}{*}{ B. tequilensis PS21 } & 27 & 27 & 25 & 31 & 27 & 5 \\
\hline & $\mathrm{S}$ & $\mathrm{S}$ & $\mathrm{S}$ & $\mathrm{S}$ & $\mathrm{S}$ & $\mathrm{S}$ \\
\hline \multirow[t]{2}{*}{ Bacillus spp. PS15 } & 22 & 0 & 22 & 0 & 0 & 0.1 \\
\hline & $\mathrm{S}$ & $\mathrm{R}$ & $S$ & $\mathrm{R}$ & $\mathrm{R}$ & $\mathrm{S}$ \\
\hline Lactobacillus casei & 23 & 18 & 29 & 22 & 20 & 15 \\
\hline WS13 & $\mathrm{S}$ & M & $\mathrm{S}$ & $\mathrm{S}$ & $\mathrm{S}$ & M \\
\hline Meyerozyma & 25 & 18 & 27.5 & 22 & 19 & 0 \\
\hline guilliermondii $\mathrm{TC} 15$ & $\mathrm{~S}$ & M & $\mathrm{S}$ & $\mathrm{S}$ & M & $\mathrm{R}$ \\
\hline Acetobacter & 25 & 21 & 28 & 23.5 & 21 & 3 \\
\hline pasteurianus WS4 & $S$ & S & $S$ & $\mathrm{~S}$ & S & $S$ \\
\hline Lactobacillus casei & 25 & 13.5 & 28 & 21 & 14.5 & 7.5 \\
\hline WS15 & $\mathrm{S}$ & $\mathrm{R}$ & $\mathrm{S}$ & $\mathrm{S}$ & $\mathrm{R}$ & M \\
\hline Saccharomyces & 26 & 26 & 31 & 26 & 20 & 10 \\
\hline cerevisiae TC6 & $\mathrm{S}$ & $\mathrm{S}$ & $\mathrm{S}$ & $\mathrm{S}$ & $\mathrm{S}$ & M \\
\hline Pedicoccus pentosaceus & 20 & 22.5 & 26 & 25 & 0 & 1 \\
\hline WS12 & $\mathrm{S}$ & $\mathrm{S}$ & $\mathrm{S}$ & $\mathrm{S}$ & $\mathrm{R}$ & $\mathrm{S}$ \\
\hline \multirow[t]{2}{*}{ P. pentosaceus WS11 } & 23 & 17 & 30 & 12.5 & 0 & 5 \\
\hline & $\mathrm{S}$ & M & $\mathrm{S}$ & $\mathrm{R}$ & $\mathrm{R}$ & $\mathrm{S}$ \\
\hline \multirow[t]{2}{*}{ A. pasteurianus WS3 } & 26.5 & 27.5 & 26.5 & 24.5 & 23 & 3 \\
\hline & $\mathrm{S}$ & $\mathrm{S}$ & $\mathrm{S}$ & $\mathrm{S}$ & $\mathrm{S}$ & $\mathrm{S}$ \\
\hline \multirow[t]{2}{*}{ A. pasteurianus WS7 } & 20.5 & 24.5 & 27.5 & 0 & 20.5 & 0.1 \\
\hline & $\mathrm{S}$ & $\mathrm{S}$ & $\mathrm{S}$ & $\mathrm{R}$ & $\mathrm{S}$ & $\mathrm{S}$ \\
\hline Lactococcus lactis & 23 & 21 & 22 & 23 & 22 & 0.1 \\
\hline subsp. lactis TBRC 375 & $\mathrm{~S}$ & $\mathrm{~S}$ & $\mathrm{~S}$ & $\mathrm{~S}$ & $\mathrm{~S}$ & $\mathrm{~S}$ \\
\hline \multirow{2}{*}{ L. brevis TBRC 3003} & 24 & 21 & 23 & 24 & 22 & 0.1 \\
\hline & $\mathrm{S}$ & $\mathrm{S}$ & $\mathrm{S}$ & $\mathrm{S}$ & $\mathrm{S}$ & $\mathrm{S}$ \\
\hline Bifidobacterium & 25 & 22.5 & 25 & 23.5 & 23 & 0.1 \\
\hline adolescentisTBRC 7154 & $S$ & $\mathrm{~S}$ & $\mathrm{~S}$ & $\mathrm{~S}$ & $\mathrm{~S}$ & $\mathrm{~S}$ \\
\hline
\end{tabular}

$\%$ hydrophobicity ranging from 1.89 to $16.46 \%$. $E$. xiangfangensis $4 \mathrm{~A}-2 \mathrm{~A} 3.1$ was found to have the highest $\%$ hydrophobicity of $13.57 \%$ among microbes tested whereas E. ludwigii S1E9, E. ludwigii 1B-2, Bacillus spp. PS15, and $P$. pentosaceus WS12 showed no hydrophobicity property at all (Table 3).

Seven out of twelve microbes were selected for the next test. Tolerance of microbes to acidic condition in human stomach and bile in the intestine is important to enable the strain survival in acid rich-foods for longer time without a decrease in microbial population and persistence in intestinal habitat. Only four strains from the previous test were examined for acid and bile tolerance. The findings showed that all four selected isolates and three reference strains showed similarly high survival rate (90.45-99.78\%) in simulated gastric juice $\mathrm{pH} 3.0$ for $1.30 \mathrm{~h}$, which indicated their resistance towards the acidic $\mathrm{pH}$ (Table 4). Similarly, high survival rate of $95.66-100.00 \%$ in $0.3 \%$ bile salts for 3 $\mathrm{h}$ was also detected among all the strains indicating that they were tolerant towards intestinal habitat (Table 4).

\section{Neurotransmitter-producing capacity of microbes}

Results of this study disclosed that only two bacteria including E. xiangfangensis 4A-2A3.1 and Bacillus spp. PS15 were found to produce GABA following $20 \mathrm{mg} / \mathrm{mL}$ MSG treatment (Table 5; Fig. 2). GABA production remained rather constant at $4.60 \mu \mathrm{g} / \mathrm{mL}$ over 2 days for $E$. xiangfangensis 4A-2A3.1; however, Bacillus spp. PS15 produced the highest GABA at $5.57 \mu \mathrm{g} / \mathrm{mL}$ on day 1 and afterwards decreased rapidly to 1.42 and $1.01 \mu \mathrm{g} / \mathrm{mL}$ on day 2 and 3 , respectively. This may be a result of GABA 
Table 3: Percentage of hydrophobicity of microbes

\begin{tabular}{lll}
\hline No. & Microbial strains & Hydrophobicity (\%) \\
\hline 1 & Enterobacter ludwigii S1E9 & $0.00 \pm 0.00^{\mathrm{e}}$ \\
2 & Enterobacter xiangfangensis 4A-2A3.1 & $13.57 \pm 1.85^{\mathrm{ab}}$ \\
3 & Enterococcus casseliflavus 3.10A1 & $1.89 \pm 0.15^{\mathrm{d}}$ \\
4 & Enterobacter ludwigii 1B-2 & $0.00 \pm 0.00^{\mathrm{e}}$ \\
5 & Bacillus spp. PS15 & $0.00 \pm 0.00^{\mathrm{e}}$ \\
6 & Meyerozyma guilliermondii TC15 & $5.75 \pm 1.63^{\mathrm{c}}$ \\
7 & Saccharomyces cerevisiae TC6 & $5.73 \pm 1.61^{\mathrm{c}}$ \\
8 & Pedicoccus pentosaceus WS12 & $0.00 \pm 0.00^{\mathrm{e}}$ \\
9 & Pedicoccus pentosaceus WS11 & $12.28 \pm 5.20^{\mathrm{ab}}$ \\
10 & Lactococcus lactis subspp. lactis TBRC 375 & $16.46 \pm 5.45^{\mathrm{a}}$ \\
11 & Lactobacillus brevis TBRC 3003 & $13.66 \pm 0.93^{\mathrm{ab}}$ \\
12 & Bifidobacterium adolescentis TBRC 7154 & $14.38 \pm 1.39^{\mathrm{ab}}$
\end{tabular}

Table 4: Acid and bile tolerance of microbes

\begin{tabular}{|c|c|c|c|c|c|c|}
\hline \multirow{3}{*}{ Microbial strains } & \multirow{2}{*}{\multicolumn{2}{|c|}{$\frac{\text { Gastric juice pH } 3.0}{\text { Cells }\left(\log _{10} \mathrm{CFU} / \mathrm{mL}\right)}$}} & \multicolumn{4}{|c|}{$0.3 \%$ bile salts } \\
\hline & & & & Cells (lo & $\left.{ }_{0} \mathrm{CFU} / \mathrm{mL}\right)$ & \\
\hline & $0 \mathrm{~h}$ & $1.30 \mathrm{~h}$ & Survival rate (\%) & $0 \mathrm{~h}$ & $3 \mathrm{~h}$ & Survival rate $(\%)$ \\
\hline E. casseliflavus 3.10A1 & $11.00 \pm 0.23^{\mathrm{a}}$ & $10.36 \pm 0.69^{\mathrm{a}}$ & 94.18 & $8.94 \pm 0.69^{\mathrm{a}}$ & $8.55 \pm 0.25^{\mathrm{a}}$ & 95.66 \\
\hline E. xiangfangensis $4 \mathrm{~A}-2 \mathrm{~A} 3.1$ & $9.25 \pm 0.01^{\mathrm{a}}$ & $9.23 \pm 0.09^{a}$ & 99.78 & $9.27 \pm 0.45^{\mathrm{a}}$ & $9.06 \pm 0.16^{\mathrm{a}}$ & 97.75 \\
\hline S. cerevisiae TC6 & $10.08 \pm 0.21^{\mathrm{a}}$ & $10.01 \pm 0.11^{\mathrm{a}}$ & 99.30 & $8.84 \pm 0.06^{\mathrm{a}}$ & $8.61 \pm 0.17^{\mathrm{a}}$ & 97.41 \\
\hline P. pentosaceus WS11 & $10.89 \pm 0.16^{\mathrm{a}}$ & $10.84 \pm 0.01^{\mathrm{a}}$ & 99.54 & $8.97 \pm 0.01^{\mathrm{a}}$ & $8.84 \pm 0.03^{\mathrm{a}}$ & 98.58 \\
\hline $\begin{array}{l}\text { L. lactis subspp. lactis } \\
\text { TBRC } 375\end{array}$ & $11.00 \pm 0.05^{\mathrm{a}}$ & $9.95 \pm 1.48^{\mathrm{b}}$ & 90.45 & $8.74 \pm 1.48^{b}$ & $8.66 \pm 0.33^{\mathrm{a}}$ & 99.00 \\
\hline L. brevis TBRC 3003 & $10.85 \pm 0.09^{\mathrm{a}}$ & $10.81 \pm 1.04^{b}$ & 99.68 & $9.00 \pm 0.00^{\mathrm{a}}$ & $9.00 \pm 0.00^{\mathrm{a}}$ & 100.00 \\
\hline B. adolescentis TBRC 7154 & $10.84 \pm 0.09^{\mathrm{a}}$ & $10.72 \pm 0.08^{b}$ & 98.94 & $8.99 \pm 0.15^{\mathrm{a}}$ & $8.88 \pm 0.35^{\mathrm{a}}$ & 98.77 \\
\hline
\end{tabular}

Table 5: Microbial production of GABA over $72 \mathrm{~h}$

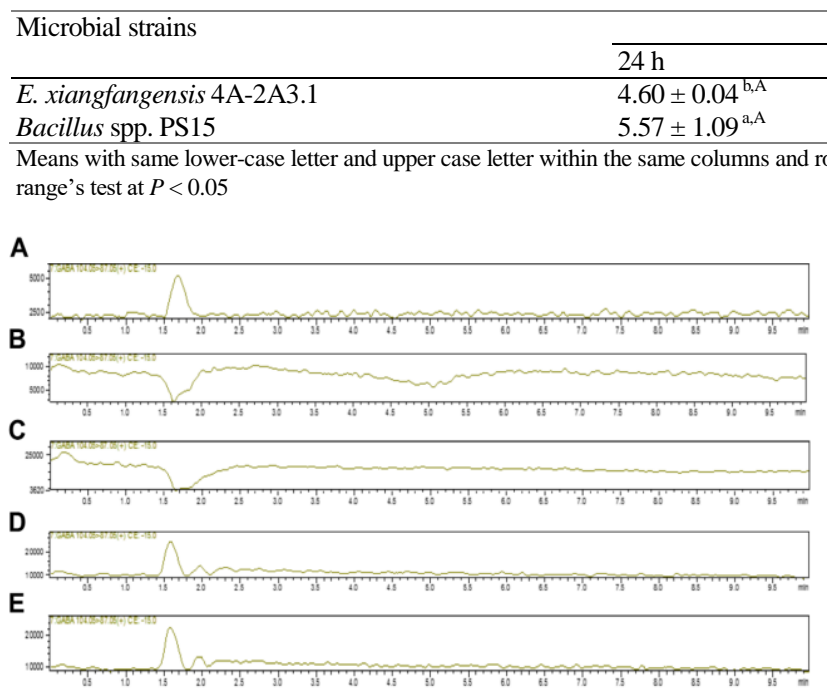

Fig. 2: LC-MS/MS chromatograms of GABA standard and GABA detection in bacterial cultures. A: GABA standard (1 ppm). B: Control (media supplemented with substrates and cofactor without bacterial culture). C: Control (microbes not producing GABA). D: GABA detection in Bacillus spp. PS15. E: GABA detection in E. xiangfangensis 4A-2A3.1

degradation or conjugated to other microbial products over time. Unfortunately, none of microbes studied in this work produce any other neurotransmitters such as serotonin, dopamine or melatonin (data not shown).
GABA production $(\mu \mathrm{g} / \mathrm{mL})$ at each incubation time

$\begin{array}{ll}48 \mathrm{~h} & 72 \mathrm{~h} \\ 4.59 \pm 0.28^{\mathrm{a}, \mathrm{A}} & 1.21 \pm 0.12^{\mathrm{a}, \mathrm{B}} \\ 1.42 \pm 0.22^{\mathrm{b}, \mathrm{B}} & 1.01 \pm 0.03^{\mathrm{b}, \mathrm{C}}\end{array}$

$1.01 \pm 0.03^{\mathrm{b}, \mathrm{C}}$

\section{Cytotoxicity of microbial extracts against cancer cells}

Microbial products have been known as good candidates for anticancer agents due to a plethora of bioactive molecules such as antioxidant enzymes, secondary metabolites and bioactive peptides. The results showed that all five microbial strains inhibited HepG2, MCF-7 and HeLa cells in a dose-dependent manner (Fig. 3). HepG2 cells were most susceptible to microbial extracts as observed by the highest cytotoxicity $(\%)$ in most concentrations, while MCF-7 cells were most resistant as observed by the lowest cytotoxicity (\%) in most concentrations (Fig. 3).

The lowest half maximal inhibitory concentration $\left(\mathrm{IC}_{50}\right)$ values of $681.08 \mu \mathrm{g} / \mathrm{mL}$ on $\mathrm{HepG} 2,750.02 \mu \mathrm{g} / \mathrm{mL}$ on MCF-7 and $425.50 \mu \mathrm{g} / \mathrm{mL}$ on HeLa, respectively were found from B. adolescentis TBRC 7154 extracts (Table 6). This strain was most cytotoxic towards three cancer cells followed by E. xiangfangensis 4A-2A3.1, E. casseliflavus $3.10 \mathrm{~A} 1$ and $P$. pentosaceus $\mathrm{WS} 11$ as seen by lower $\mathrm{IC}_{50}$ values. Doxorubicin, one of the most extensively used commercial anticancer drug, was used as a positive control. It showed the lowest $\mathrm{IC}_{50}$ values against all cancer cell lines 
Table 6: $\mathrm{IC}_{50}(\mu \mathrm{g} / \mathrm{mL})$ of crude microbial extracts for cytotoxic activity against cancer cells

\begin{tabular}{llll}
\hline Microbial strains & $\mathrm{HepG} 2$ & $\mathrm{MCF}-7$ & $\mathrm{HeLa}$ \\
\cline { 2 - 4 } & $\mathrm{IC}_{50}(\mu \mathrm{g} / \mathrm{mL})$ & $\mathrm{IC}_{50}(\mu \mathrm{g} / \mathrm{mL})$ & $\mathrm{IC}_{50}(\mu \mathrm{g} / \mathrm{mL})$ \\
\hline E. xiangfangensis 4A-2A3.1 & $684.48 \pm 1.62 \mathrm{~b}, \mathrm{~B}$ & $806.25 \pm 0.53 \mathrm{f}, \mathrm{C}$ & $468.16 \pm 0.87 \mathrm{~d}, \mathrm{~A}$ \\
E. casseliflavus 3.10A1 & $710.81 \pm 0.34 \mathrm{~d}, \mathrm{~B}$ & $752.07 \pm 0.69 \mathrm{~b}, \mathrm{C}$ & $549.54 \pm 0.57 \mathrm{f}, \mathrm{A}$ \\
P. pentosaceus WS11 & $707.54 \pm 0.49 \mathrm{c}, \mathrm{B}$ & $772.08 \pm 1.31 \mathrm{c}, \mathrm{C}$ & $437.07 \pm 1.48 \mathrm{c}, \mathrm{A}$ \\
L. lactis subspp. lactis TBRC 375 & $704.20 \pm 1.26 \mathrm{c}, \mathrm{B}$ & $777.36 \pm 1.00 \mathrm{~d}, \mathrm{C}$ & $524.45 \pm 0.16 \mathrm{e}, \mathrm{A}$ \\
B. adolescentis TBRC 7154 & $681.08 \pm 1.31 \mathrm{c}, \mathrm{B}$ & $750.02 \pm 1.00 \mathrm{~d}, \mathrm{C}$ & $425.50 \pm 0.26 \mathrm{e}, \mathrm{A}$ \\
Doxorubicin & $9.10 \pm 0.22$ & $7.04 \pm 0.80$ & $0.61 \pm 0.04$ \\
\hline
\end{tabular}

Means with same lower-case letter and upper case letter within the same columns and rows, respectively did not differ significantly from each other according to Duncan Multiple range's test at $P<0.05$

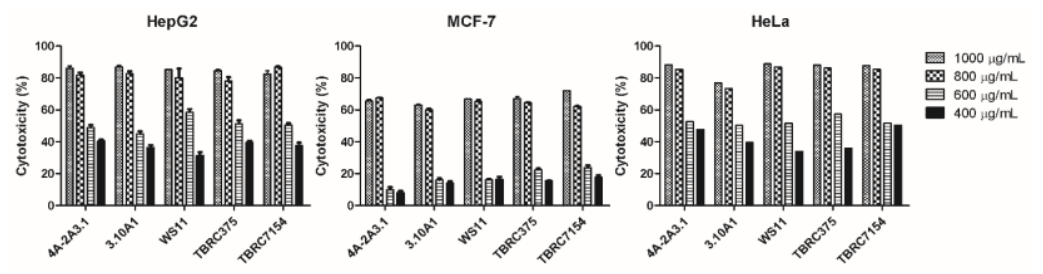

Fig. 3: Cytotoxicity of five microbial extracts in different concentrations against HepG2, MCF-7 and HeLa cells

at $0.6-9.1 \mu \mathrm{g} / \mathrm{mL}$. A negative control (broth extract without microbes) showed no cytotoxicity (data not shown).

\section{Discussion}

In this work, both strains of E. casseliflavus showed no gelatin hydrolysis. Similarly, the results of no gelatin hydrolysis of Enterobacter spp., P. pentosaceus, certain A. pasteurianus, M. guilliermondii TC15, and $S$. cerevisiae TC6 in this work were in accordance with the previous reports showing the same species with no gelatinase activity (Fakruddin et al. 2017; Chi et al. 2018; Zajc et al. 2019). This indicated greater potential use as probiotics since these strains are unlikely to express gelatinase, a metalloendopeptidase, which is able to degrade hemoglobin, insulin, collagen, casein, fibrinogen and gelatin (Kanemitsu et al. 2001) and thus may harm the hosts. It is known that the species of Enterococcus showed their expressions of gelatinase depending on the niche of isolation (Araújo and Ferreira 2013).

The auto-aggregation ability can be used as one of the indicator for probiotic attribute. This is linked to the adherence capacity to the human intestinal lining, protection of the gastrointestinal tract of the host from pathogen colonization (García-Cayuela et al. 2014) and immunomodulatory effects (Xu et al. 2010). Thus, probiotics are expected to exert high auto-aggregation. However, percentage of auto-aggregation is not directly translated to in vivo adhesion due to involvement of host factors such as normal microflora, defense mechanisms, and peristaltic rhythms that modulate the microbial attachment (Caggia et al. 2015). Interestingly, S. cerevisiae TC6 in this work showed similar percentage of auto-aggregation $(64.88 \%)$ to that of S. cerevisiae IFST062013 (61.34\%), a potential probiotic, isolated from fruit in Bangladesh (Fakruddin et al. 2017).
The previous findings showed that Enterococcus spp. exhibited $\beta$-hemolysis (Igbinosa and Beshiru 2019). In contrast to the result from this work, others have found that B. tequilensis YC5-2 (Luis-Villaseñor et al. 2011) and $B$. tequilensis FR9 (Rani et al. 2016) exhibited $\gamma$-hemolytic activity causing no health hazard. The differences of hemolytic activity may lie in specific strain genetic makeup. Contrary to popular belief, hemolytic activity was found in Bacillus, but it is used as commercial human probiotics (Hoa et al. 2001). Although the in vitro hemolysis does not always result in any negative effect to fish and pigs (Trapecar et al. 2011), EFSA guidelines do not recommend hemolysin-producing microbes as feed additives (European Food Safety Authority 2011).

In this work, most of the tested microbial strains appeared to be moderate susceptible or susceptible to most of the six antibiotics suggesting they may have probiotic potential since they are not likely to have transferrable antibiotics resistance genes to pathogens. However, E. ludwigii S1E9, Enterobacter spp. 1B-2 and Bacillus spp. PS15 were found resistant to three or four antibiotics indicating that they may be used for patients undertaking long-term antibiotic remedy.

The previous study showed that certain Bacillus clausii with specific antibiotic resistance mechanisms has been used as probiotics in humans for the treatment of infectious bacterial diarrhea (Bozdogan et al. 2014).

In contrast to this finding, the hyl gene has also been found in E. casseliflavus recovered from food (Trivedi et al. 2011). The conflicting results from this work and of other report concerning the presence of virulence genes among microbial isolates might be resulted from differences in the reservoir of the various countries or the ecological origin of strains (Gulhan et al. 2015).

The findings in this work were supported by Sica et al. (2012) showing that $P$. pentosaceus S17 and S19 had very 
low hydrophobicity to n-hexadecane at $0.01 \%$ and $E$. mundtii $\mathrm{S} 21$ at $0.05 \%$. S. cerevisiae VIT-ASN03 was reported to exhibit only $4 \%$ hydrophobicity (Suvarna et al. 2012) which was similar to $S$. cerevisiae TC6 in this work. In contrast, the previous study showed a much higher hydrophobicity value of $52.4 \%$ for L. lactis DF04Mi (Furtado et al. 2014) when compared to $16.46 \%$ from $L$. lactis subs. lactis TBRC 375 in this work. It is known that hydrophobicity variation can occur among related species and same species (Schar-Zammaretti and Ubbink 2003). Although, certain strains had a high cell surface hydrophobicity, they were not able to properly attach to HT29 and Caco-2 cells (Todorov et al. 2008). However, a relatively low hydrophobicity $(38 \%)$ strain, L. pentosus ST712BZ, attached to HT-29 cells at $63 \%$. Hydrophobicity may partly contribute to adhesion, but it is not a requirement for strong adherence to human intestinal cells. In addition, the physiology of the cell, availability of nutrient and $\mathrm{pH}$ of the microbial cultivation medium also influence physiochemical properties of the microbial cell surface (Hamadi et al. 2004).

Similarly, certain yeast strains $S$. cerevisiae from various sources have been documented as acid- and biletolerant (Agarwal et al. 2001; Helmy et al. 2019; Kim et al. 2019). Other authors found similarly high survival ability of P. pentosaceus (Ilavenil et al. 2016; Zommiti et al. 2018; Ladha and Jeevaratnam 2018). In contrast to this result, the other report showed that E. casseliflavus WECA01 exhibited weak bile resistance at $30.50 \%$ survival rate (Zhang et al. 2016).

This is the first report of E. xiangfangensis as GABA producer, which may express glutamate decarboxylase (GAD), the enzyme that catalyzes the biosynthesis of GABA from decarboxylating glutamate to GABA (Dhakal et al. 2012). However, its GABA production was much lower in this work compared to the commonly found GABA-producing LAB strains.

Previously, L. brevis DPC6108 isolated from human intestine was found to produce GABA at $20.47 \mathrm{mg} / \mathrm{mL}$ from $20 \mathrm{mg} / \mathrm{mL}$ MSG over 2 days (Barrett et al. 2012). In literature, very few findings have reported the GABAproducing capacity from Bacillus spp. In this work, Bacillus spp. PS15 was found to produce very low GABA amount over 3 days, compared to the previously reported Bacillus subtilis ATCC 6051 with the highest GABA production at $19.74 \mathrm{mg} / \mathrm{mL}$ for $120 \mathrm{~h}$ (Wang et al. 2018). It is thought that the optimum conditions differ from one microbe to the next due to the different characteristics of the GADs (Dhakal et al. 2012) and thus effects of temperature, $\mathrm{pH}$, media additives, and cultivation time should be investigated to achieve the highest GABA production. GABA is one of the major inhibitory neurotransmitter in the mammalian central nervous system. GABA helps increase the growth hormones, plasma concentration and the synthesis of protein in the brain (Cho et al. 2007). The GABA-producing strains are of great interest to be used to manufacture GABA-enrich food products (Coda et al. 2010).

When compared to the previous finding (Phonnok et al. 2010), most of the microbes in this work still had much lower cytotoxicity against cancer cells as observed by high $\mathrm{IC}_{50}$ values. The differences in cytotoxicity may lie in genetics of each strain, different genes responsible for producing bioactive compounds such as immune toxins, antioxidant enzymes, secondary metabolites, exopolysaccharides, and bioactive peptides that account for anticancer effects.

\section{Conclusion}

Only seven microbial strains confer most promising probiotic potential with safety for use in humans; $E$. casseliflavus 3.10A1, E. xiangfangensis 4A-2A3.1, S. cerevisiae TC6, P. pentosaceus WS11, L. lactis subspp. lactis TBRC 375, L. brevis TBRC 3003 and B. adolescentis TBRC 7154. In addition, E. xiangfangensis 4A-2A3.1 and Bacillus spp. PS15 were found to be GABA producers which may be used as ingredients in cocktails or pills or GABA-enrich food products to prevent GABA-deficient mental disorders. Moreover, B. adolescentis TBRC 7154, E. xiangfangensis 4A-2A3.1, E. casseliflavus 3.10A1, P. pentosaceus WS11 and L. lactis subspp. lactis TBRC 375 displayed cytotoxic effects against HepG2, MCF-7 and HeLa. These microbes may be used as potential biotherapeutic reagents or food supplements to prevent cancer.

\section{Acknowledgments}

This research was financially supported by Mahasarakham University (Fast Track 2020). The authors would like to thank Department of Biotechnology, Faculty of Technology, Mahasarakham University (MSU), Thailand and Central Laboratory at MSU for research facilities.

\section{Author Contributions}

VL designed, conducted the experiments, analyzed data and wrote the manuscript. WS and TK conducted the experiments. BB and SD designed the experiments. SNT, NLM and AN edited the manuscript draft. All authors listed have read and approved the manuscript for publication.

\section{References}

Agarwal N, DN Kamra, LC Chaudhary, A Sahoo, NN Pathak (2001). Selection of Saccharomyces cerevisiae strains for use as a microbial feed additive. Lett Appl Microbiol 31:270-273

Araújo TF, CLLF Ferreira (2013). The genus Enterococcus as probiotic: Safety concerns. Braz Arch Biol Technol 56:457-466

Barrett E, RP Ross, PW O'Toole, GF Fitzgerald, C Stanton (2012). $\gamma$ Aminobutyric acid production by culturable bacteria from the human intestine. J Appl Microbiol 113:411-417

Bozdogan B, S Galopin, R Leclercq (2004). Characterization of a new ermrelated macrolide resistance gene present in probiotic strains of Bacillus clausii. Appl Environ Microbiol 70:280-284 
Caggia C, MD Angelis, I Pitino, A Pino, C Randazzo (2015). Probiotic features of Lactobacillus strains isolated from Ragusano and pecorino Siciliano cheeses. Food Microbiol 50:109-117

Chi Q, W Tang, L Liu, J Meng, X Dong, W Chen, X Li (2018). Isolation and properties of Enterobacter spp. LX3 capable of producing indoleacetic acid. Appl Sci 8:2108-2118

Cho YR, JY Chang, HC Chang (2007). Production of gamma-aminobutyric acid (GABA) by Lactobacillus buchneri isolated from kimchi and its neuroprotective effect on neuronal cells. J Microbiol Biotechnol 17:104-109

Chuang-Smith ON, CL Wells, MJ Henry-Stanley, GM Dunny (2010). Acceleration of Enterococcus faecalis biofilm formation by aggregation substance expression in an ex vivo model of cardiac valve colonization. PLoS One 5; Article e15798

Claesson MJ, IB Jeffery, S Conde, SE Power, EM O'Connor, S Cusack, HMB Harris, M Coakley, B Lakshminarayanan, O O'Sullivan, GF Fitzgerald, J Deane, M O'Connor, N Harnedy, K O'Connor, D O'Mahony, D van Sinderen, M Wallace, L Brennan, C Stanton, JR Marchesi, AP Fitzgerald, F Shanahan, C Hill, RP Ross, PW O'Toole (2012). Gut microbiota composition correlates with diet and health in the elderly. Nature 488:178-184

Coda R, CG Rizzello, M Gobbetti (2010). Use of sourdough fermentation and pseudo-cereals and leguminous flours for the making of a functional bread enriched of $\gamma$-aminobutyric acid (GABA). Intl $J$ Food Microbiol 137:236-245

Collado M, CJ Meriluoto, S Salminen (2008). Adhesion and aggregation properties of probiotic and pathogen strains. Eur Food Res Technol 226:1065-1073

Davari S, SA Talaei, H Alaei, M Salami (2013). Probiotics treatment improves diabetes-induced impairment of synaptic activity and cognitive function: Behavioral and electrophysiological proofs for microbiome-gut-brain axis. Neuroscience 14:287-296

Dhakal R, VK Bajpai, KH Baek (2012). Production of GABA $(\gamma$ aminobutyric acid) by microorganisms: A review. Braz J Microbiol 43:1230-1241

Dinan TG, C Stanton, JF Cryan (2013). Psychobiotics: A novel class of psychotropic. Biol Psych 74:720-726

European Food Safety Authority (2011). Scientific opinion on the maintenance of the list of QPS biological agents intentionally added to food and feed. Eur Food Saf Author J 9:2497-2603

Fakruddin M, MN Hossain, MM Ahmed (2017). Antimicrobial and antioxidant activities of Saccharomyces cerevisiae IFST062013, a potential probiotic. BMC Complem Altern Med 17; Article 64

Furtado DN, SD Todorov, M Landgraf, MT Destro, BD Franco (2014). Bacteriocinogenic Lactococcus lactis subspp. lactis DF04Mi isolated from goat milk: Evaluation of the probiotic potential. Braz Microbiol 45:1047-1054

García-Cayuela T, AM Korany, I Bustos, LPGD Cadiñanos, T Requena, C Peláez, MC Martínez-Cuesta (2014). Adhesion abilities of dairy Lactobacillus plantarum strains showing an aggregation phenotype. Food Res Intl 57:44-50

Grajek K, A Sip, J Foksowicz-Flaczyk, A Dobrowolska, A Wita (2016) Adhesive and hydrophobic properties of the selected LAB isolated from gastrointestinal tract of farming animals. Acta Biochim Pol 63:311-314

Gulhan T, B Boynukara, A Ciftci, MU Sogut, A Findik (2015). Characterization of Enterococcus faecalis isolates originating from different sources for their virulence factors and genes, antibiotic resistance patterns, genotypes and biofilm production. Iran J Vet Res 16:261-266

Guo L, T Li, Y Tang, L Yang, G Huo (2015). Probiotic properties of Enterococcus strains isolated from traditional naturally fermented cream in China. Micro Biotechnol 9:737-745

Hamadi F, H Latrache, A El Ghmari, M Ellouali, M Mabrrouki, N Kouider (2004). Effect of $\mathrm{pH}$ and ionic strength on hydrophobicity and electron donor and acceptor characteristics of Escherichia coli and Staphylococcus aureus. Ann Microbiol 54:213-225

Helmy EA, SA Soliman, TM Abdel-Ghany, M Ganash (2019). Evaluation of potentially probiotic attributes of certain dairy yeast isolated from buffalo sweetened Karish cheese. Heliyon 5; Article e01649
Hoa TT, LH Duc, R Isticato, L Baccigalupi, E Ricca, PH Van (2001). Fate and dissemination of Bacillus subtilis spores in a murine model. Appl Environ Microbiol 67:3819-3823

Hsiao EY, SW McBride, S Hsien, G Sharon, ER Hyde, T McCue, SK Mazmanian (2013). The microbiota modulates gut physiology and behavioral abnormalities associated with autism. Cell 155:1451-1463

Igbinosa EO, A Beshiru (2019). Antimicrobial resistance, virulence determinants, and biofilm formation of Enterococcus species from ready-to-eat seafood. Front Microbiol 10; Article 728

Ilavenil S, M Vijayakumar, DH Kim, MV Arasu, HS Park, S Ravikumar, KC Choi (2016). Assessment of probiotic, antifungal and cholesterol lowering properties of Pediococcus pentosaceus KCC-23 isolated from Italian ryegrass. J Sci Food Agric 96:593-601

Jiao J, Y Ma, S Chen, C Liu, Y Song, Y Qin, Y Liu (2016). Melatoninproducing endophytic bacteria from grapevine roots promote the abiotic stress-induced production of endogenous melatonin in their hosts. Front Plant Sci 7; 1387

Kanemitsu K, T Nishino, H Kunishima, N Okamura, H Takemura, H Yamamoto, M Kaku (2001). Quantitative determination of gelatinase activity among enterococci. J Microbiol Meth 47:11-16

Kim JA, J Bayo, J Cha, YJ Choi, MY Jung, DH Kim, Y Kim (2019). Investigating the probiotic characteristics of four microbial strains with potential application in feed industry. PLoS One 14; Article e0218922

Kim RU, SC Ahn, SN Yu, KY Kim, JH Seong, YG Lee, HS Kim, DS Kim (2011). Screening and identification of soy curd-producing lactic acid bacteria. J Life Sci 21:235-241

Ladha G, K Jeevaratnam (2018). Probiotic potential of Pediococcus pentosaceus LJR1, a bacteriocinogenic strain isolated from rumen liquor of goat (Capra aegagrus hircus). Food Biotechnol 32:60-77

Lapsiri W, S Nitisinprasert, P Wanchaitanawong (2011). Lactobacillus plantarum strains from fermented vegetables as potential probiotics. Kasetsart J Nat Sci 45:1071-1082

Luang-In V, S Deeseenthum (2016). Exopolysaccharide-producing isolates from Thai milk kefir and their antioxidant activities. LWT-Food Sci Technol 73:592-601

Luang-In V, S Deeseenthum, P Udomwong, W Saengha, M Gregori (2018a). Formation of sulforaphane and iberin products from Thai cabbage fermented by myrosinase-positive bacteria. Molecules 23; Article 955

Luang-In V, W Saengha, M Yotchaisarn, M Halaslova, P Udomwong, S Deeseenthum (2018b). Microbial strains and bioactive exopolysaccharide producers from Thai water kefir. Microbiol Biotechnol Lett 46:403-415

Luis-Villaseñor IE, ME Macías-Rodríguez, B Gómez-Gil, F AscencioValle, ÁI Campa-Córdova (2011). Beneficial effects of four Bacillus strains on the larval cultivation of Litopenaeus vannamei. Aquaculture 321:136-144

Phonnok S, W Uthaisang-Tanechpongtamb, BT Wongsatayanon (2010). Anticancer and apoptosis-inducing activities of microbial metabolites. Electr J Biotechnol 13:1-12

Rani RP, M Anandharaj, S Hema, R Deepika, A David Ravindran (2016). Purification of antilisterial peptide (Subtilosin A) from novel Bacillus tequilensis FR9 and demonstrate their pathogen invasion protection abilityusinghuman carcinomacell line.Front Microbiol 7; Article 1910

Schar-Zammaretti P, J Ubbink (2003). The cell wall of lactic acid bacteria: Surface constituents and macromolecular conformations. Biophys $J$ 85:4076-4092

Sica MG, LI Brugnoni, PL Marucci, MA Cubitto (2012). Characterization of probiotic properties of lactic acid bacteria isolated from an estuarine environment for application in rainbow trout (Oncorhynchus mykiss, Walbaum) farming. Anton Leeuwen 101:869-879

Siddiqui MA, R Wahab, J Ahmad, NN Farshori, J Musarrat, AA Alkhedhairy (2017). Evaluation of cytotoxic responses of raw and functionalized multi-walled carbon nanotubes in human breast cancer (MCF-7) cells. Vaccum 146:578-585

Suvarna S, J Dsouza, ML Ragavan, N Das (2012). Potential probiotic characterization and effect of encapsulation of probiotic yeast strains on survival in simulated gastrointestinal tract condition. Food Sci Biotechnol 27:745-753 
Todorov SD, M Botes, C Guigas, U Schillinger, I Wiid, MB Wachsman, WH Holzapfel, LMT Dicks (2008). Boza, a natural source of probiotic lactic acid bacteria. J Appl Microbiol 104:465-477

Trapecar M, T Leouffre, M Faure, HE Jensen, PE Granum, A Cencic, SP Hardy (2011). The use of a porcine intestinal cell model system for evaluating the food safety risk of Bacillus cereus probiotics and the implications for assessing enterotoxigenicity. Acta Pathol Microbiol Immunol Scand 119:877-884

Trivedi K, S Cupakova, R Karpiskova (2011). Virulence factors and antibiotic resistance in Enterococci isolated from food-stuffs. Vet Med 56:352-357

Wang H, J Huang, L Sun, F Xu, W Zhang, J Zhan (2018). An efficient process for co-production of $\gamma$-aminobutyric acid and probiotic Bacillus subtilis cells. Food Sci Biotechnol 28:155-163

Wayne PA (2002). National committee for clinical laboratory standards. Perform Stand Antimicrob Disc Suscept Test 12:1-53

Weinstein LC, A Stefancic, AT Cunningham, KE Hurley, LJ Cabassa, RC Wender (2016). Cancer screening, prevention, and treatment in people with mental illness. Cancer J Clin 66:134-151
Xu Z, L Li, ME Shirtliff, BM Peters, Y Peng, MJ Alam, L Shi (2010). First report of class 2 integron in clinical Enterococcus faecalis and class 1 integron in Enterococcus faecium in South China. Diagn Microbiol Infect Dis 68:315-317

Yamane T, T Sakamoto, T Nakagaki, Y Nakano (2018). Lactic acid bacteria from kefir increase cytotoxicity of natural killer cells to tumor cells. Foods 7; Article 48

Zajc J, C Gostinčar, A Černoša, N Gunde-Cimerman (2019). Stress-tolerant yeasts: Opportunistic pathogenicity versus biocontrol potential. Genes 10; Article 42

Zhang F, M Jiang, C Wan, X Chen, X Chen, X Tao, NP Shah, H Wei (2016). Screening probiotic strains for safety: Evaluation of virulence and antimicrobial susceptibility of enterococci from healthy Chinese infants. J Dairy Sci 99:4282-4290

Zommiti M, M Cambronel, O Maillot, M Barreau, K Sebei, M Feuilloley, N Connil (2018). Evaluation of probiotic properties and safety of Enterococcus faecium isolated from Artwasanal Tunwasian meat "Dried Ossban". Front Microbiol 9; Article 1685 